\title{
EFEK ADVERSITY INTELLIGENCE DAN PERSEPSI MAHASISWA MEMAHAMI PROFESI GURU TERHADAP KEPERCAYAAN DIRI MENJADI GURU
}

\author{
Galih Prihatiandy \\ Setiadi Cahyono Putro \\ Hari Putranto
}

\begin{abstract}
Abstrak: Tujuan penelitian ini untuk mengungkap hubungan dan sumbangan adversity intelligence $\left(\mathrm{X}_{1}\right)$ dan persepsi mahasiswa memahami profesi guru $\left(\mathrm{X}_{2}\right)$ dengan kepercayaan diri menjadi guru (Y). Penelitian ini adalah penelitian expose facto dengan rancangan penelitian deskriptif korelasional. Sampel penelitian adalah mahasiswa S1 PTE angkatan 2013 sejumlah 106 responden. Teknik pengumpulan data menggunakan angket, reliabilitas (apha cronbach) $\mathrm{X}_{1}, \mathrm{X}_{2}$, dan $\mathrm{Y}$ secara berturut-turut adalah 0,90; 0,95; dan 0,93. Analisis data menggunakan analisis Regresi Linear Ganda. Hasil penelitian menunjukkan terdapat hubungan yang signifikan antara $X_{1}$ dan $X_{2}$ dengan $Y$ baik secara parsial maupun simultan dan Sumbangan efektif $X_{1}$ terhadap $Y$ sebesar $30,05 \%$, dan $\mathrm{X}_{2}$ terhadap $\mathrm{Y}$ sebesar $4,30 \%$. Efek adversity intelligence terhadap kepercayaan diri untuk menjadi guru lebih tinggi dibanding persepsi mahasiswa dalam memahami profersi guru.
\end{abstract}

Kata-kata Kunci: adversity intelligence, persepsi mahasiswa, profesi keguruan, kepercayaan diri

Abstract: Effect Adversity Intelligence and Student Perception Understanding Teacher Professions to Self-Trust to be a Teacher for Students Candidate Teacher. The purpose of this study was to reveal relationship and contribution of adversity intelligence (X1) and perception of student to understand teacher profession (X2) with selfconfidence become teacher $(Y)$. This research is an expose facto research with correlational descriptive research design. The sample of this research is S1 student of PTE force of 2013 number 106 respon-dents. Data collection techniques using questionnaires, reliability (apha cronbach) $X 1, X 2$, and $Y$ are 0.90 respectively; 0,95; and 0.93. Data analysis using multiple linear regression analysis. (1) there is a significant relationship between $X 1$ and $X 2$ with $Y$ either partially or simultaneously and (2) Effective contribution of $X 1$ to $Y$ is 30,05\%, and X2 to $Y$ is 4,30\%. The conclusion is that the effect of adversity intelligence on self-confidence to become teacher is higher than student perception in understanding teacher's proficiency.

Keywords: adversity intelligence, stident perception, teacher professsion, confidence

$\mathrm{P}$ eningkatan mutu dan layanan pendidikan di Indonesia sangat penting dilakukan, hal ini bertujuan untuk mencekompetitif dan berakhlak mulia. Salah satu upaya untuk meningkatkan mutu dan layanan pendidikan di Indonesia tak generasi penerus bangsa yang cerdas, adalah dengan mempersiapkan calon gu-

Galih Prihatiandy adalah Mahasiswa Teknik Elektro Universitas Negeri Malang. Email: galihgendon@gmail.com. Setiadi Cahyono Putro dan Hari Putranto adalah Dosen Jurusan Teknik Elektro Universitas Negeri Malang. Alamat Kampus: Jl. Semarang No. 5 Malang 65145. 
ru yang mempunyai kompetensi dan kriteria yang telah dipersyaratkan. Universitas Negeri Malang (UM) sebagai salah satu Lembaga Pendidikan Tenaga Kependidikan (LPTK) telah berupaya untuk menyelenggarakan pendidikan yang menyiapkan mahasiswa untuk menjadi warga negara yang cerdas, religius, berakhlak mulia, mandiri dan mampu berkembang secara profesional sebagai tenaga pengajar, dan tenaga kependidikan lain, tenaga pengembang dan ahli ilmu pendidikan dan keguruan, dan lain-lain (Universitas Negeri Malang, 2014: 1). Mahasiswa yang dididik sebagai calon guru, seharusnya memiliki kepercayaan diri dan ketertarikan untuk menjadi guru.

Namun kenyataan di lapangan menunjukkan bahwa mahasiswa Program Studi S1 Pendidikan Teknik Elektro Jurusan Teknik Elektro Fakultas Teknik Universitas Negeri Malang (Prodi S1 PTE Jurusan TE FT UM) yang memiliki minat menjadi guru yang tinggi hanya sebanyak $71,40 \%$, sedangkan yang memiliki persepsi baik terhadap karir keguruan hanya 60,20\% (Primadewi, 2016: 61-63). Selain itu ketertarikan mereka untuk menjadi guru dalam kategori yang cukup tinggi (Fitriawati, 2013: 51). Kurangnya minat untuk menjadi guru disebabkan beberapa hal yaitu seorang guru harus memiliki kriteria dan kompetensi yang telah dipersyaratkan. Hal yang mengurangi kepercayaan diri mahasiswa untuk menjadi guru.

Mahasiswa yang dididik menjadi calon guru, sudah selayaknya menguasai pengetahuan dalam dunia pendidikan dan menguasai standar kompetensi guru. Mulyasa (2013: 173) seorang guru diharapkan memiliki kompetensi sosial dalam bermasyarakat untuk mempermudah komunikasi. Dalam mempermudah komunikasi di depan umum, seorang guru harus membekali diri dengan rasa percaya diri.

Percaya diri merupakan keyakinan seseorang terhadap segala kelebihan yang dimiliki dan keyakinan tersebut membuatnya merasa mampu untuk mengendalikan diri dengan baik, sehingga dapat mencapai berbagai tujuan hidup yang telah diharapkan (Fatimah, 2006: 149 ; Hakim, 2005: 6). Sedangkan menurut Rakhmat (2007) kepercayaan diri merupakan suatu kepercayaan terhadap diri sendiri yang dimiliki oleh setiap orang dalam kehidupannya serta bagaimana orang tersebut memandang dirinya secara utuh. Azhar (2015) mengungkapkan bahwa terdapat hubungan positif dan signifikan antara kepercayaan diri dengan minat seseorang dalam beroganisasi. Hal ini menunjukkan bahwa kepercayaan diri seseorang dapat mempengaruhi minat seseorang tersebut.

Ciri-ciri seseorang yang memiliki kepercayaan diri menurut Fatimah (2006: 149-159) dan Hakim (2005: 5-6) yaitu: (1) berkependidikan dan mempunyai kecerdasan yang dapat diandalkan; (2) percaya dan mempunyai harapan yang realistik dengan kemampuan yang dimiliki; (3) mampu menetralisir ketegangan dan mengendalikan diri dengan baik; (4) mampu bersosialisasi dengan baik pada situasi apapun; (5) berani menerima dan menghadapi penolakan orang lain; dan (6) selalu memandang positif terhadap diri sendiri, orang lain dan lingkungan sekitar.

Berdasarkan uraian yang telah dipaparkan di atas, kepercayaan diri menjadi guru dapat diartikan sebagai kondisi mental atau psikologis seseorang yang memberi keyakinan kuat pada dirinya untuk melakukan dan mengendalikan tindakan yang berkaitan dengan dunia pendidikan khususnya dalam memilih karir sebagai guru.

Ciri-ciri mahasiswa yang memiliki kepercayaan diri untuk menjadi guru diantaranya: (1) memiliki keyakinan untuk menjadi guru; (2) merasa yakin menguasai teori belajar dan prinsip-prinsip pembelajaran yang mendidik; (3) memiliki 
keterampilan untuk mengelola dan mengevaluasi pembelajaran dengan baik; dan (4) merasa mampu menjalankan KPL dengan baik; (5) cenderung berbicara tenang di lingkungan sekolah; (6) tekun mengerjakan tugas akademik; (7) cenderung mengungkapkan gagasan secara jelas dan tidak terburu-buru; dan (8) tidak merasa canggung ketika presentasi di dalam kelas.

Menurut Santrock dalam Setyawan (2011: 41) banyak hal positif yang dapat dilakukan dan diperoleh setelah menjadi mahasiswa diantaranya: merasa lebih dewasa, lebih banyak pelajaran yang dapat dipelajari, memiliki banyak waktu untuk dihabiskan bersama kelompok sebaya, banyak kesempatan untuk mengeksplorasi berbagai gaya hidup, menikmati kemandirian, dan tantangan intelektual menghadapi tugas akademik.

Dengan pengetahuan dan pengalaman yang dimiliki mahasiswa diharapkan mampu berpikir lebih luas untuk menghadapi tantangan dan kesulitan yang ada di kehidupan sehari-hari. Stoltz dalam Asfarina (2016:3) mengatakan ukuran ketangguhan seseorang dalam menghadapi kesulitan disebut Adversity Quotient.

Sedangkan Goleman dalam Asfarina (2016: 3) memberi kritikan terhadap penggunaan istilah quotient karena berhubungan dengan hasil bagi antara skor kemampuan dengan usia, hal itu menyebabkan adanya pilihan istilah baru dengan menggunakan intelligence yang berarti kecerdasan dan lebih bebas dari pengaruh usia. Adversity intelligence merupakan suatu alat ukur yang dapat menunjukkan suatu kemampuan seseorang dalam bertahan dan menghadapi kesulitan hidup serta tantangan yang dialami serta terus mampu memanfaatkannya untuk proses pengembangan diri, sehingga dapat mencapai tujuan hidup (Asfarina, 2016: 4 dan Setyawan, 2011: 43).

Adversity intelligence dapat mempengaruhi suatu keberhasilan seseorang da- lam menghadapi kesulitan yang dihadapi. Anomsari (2011) mengungkapkan bahwa terdapat hubungan positif yang signifikan antara kemampuan adversity dan intensi berwirausaha pada siswa SMK YPM 1 Taman Sidoarjo. Semakin tinggi tingkat kemampuan adversity, maka akan semakin tinggi tingkat intensi berwirausaha yang ditunjukkan oleh siswa SMK YPM 1 Taman Sidoarjo.

Berdasarkan uraian di atas, dapat ditarik kesamaan pendapat bahwa adversity intelligence merupakan ketangguhan dan kecerdasan seseorang dalam menghadapi kesulitan dan mengubahnya menjadi peluang, sehingga mampu bertahan dalam menghadapi tantangan dan kesulitan demi mencapai suatu tujuan. Stoltz dalam Wijaya (2007: 122) kecerdasan dalam menghadapi kesulitan rintangan memiliki empat dimensi yaitu: control; Origin dan Ownership; reach; dan endurance. Adanya beberapa dimensi tersebut mempermudah mahasiswa dalam mengevaluasi dan mengolah rintangan dan kesulitan yang mereka hadapi dan bagaimana langkah mahasiswa dalam mengambil tindakan.

Sebagai mahasiswa calon guru diharapkan cenderung bersabar dalam mengendalikan penyimpangan di dalam kelas; tidak mudah mengeluh dalam menghadapi perkembangan kurikulum; dan tidak mudah putus asa dalam merencanakan dan mengevaluasi pembelajaran. Selain memiliki ketangguhan dalam menghadapi kesulitan, mahasiswa diharapkan mempunyai kemampuan bertahan menghadapi tantangan (Setyawan, 2011).

Kemampuan bertahan menghadapi tantangan sebagai guru yaitu: (1) tekun dan tidak mudah putus asa dalam mengikuti program keguruan; (2) memiliki kemampuan beradaptasi jika ditempatkan di seluruh wilayah Indonesia; dan (3) mampu bertahan dalam keterbatasan Program SM3T. Dengan kemampuan bertahan mahasiswa mampu menyelesaikan tan- 
tangan yang dihadapi dan dijadikannya sebagai proses mengembangkan diri untuk menjadi guru.

Manusia sebagai makhluk sosial dan sekaligus makhluk individual, maka terdapat perbedaan individu yang satu dengan individu yang lainnya (Wolberg dalam Suherdiyanto, 2012: 8). Adanya perbedaan tersebut membuat setiap individu memiliki pengamatan, pandangan, dan pendapat yang berbeda-beda terhadap sesuatu. Seperti halnya mahasiswa yang mengamati dan memberi pendapat atau tanggapan terhadap profesi guru tergantung persepsinya masing-masing. Menurut Thoha (2004: 141) persepsi pada hakikatnya adalah proses kognitif seseorang dalam memahami informasi terkait lingkungan sekitarnya, baik lewat penglihatan, pendengaran, perasaan, penghayatan, dan penciuman.

Persepsi adalah suatu proses pengorganisasian data-data indera kita terhadap stimulus yang kemudian diproses dalam proses psikologis seseorang sehingga menghasilkan tanggapan atau dorongan untuk melakukan dan menyadari sesuatu di sekeliling kita (Shaleh, 2010: 110; Walgito, 2004: 87-88). Sedangkan menurut Rakhmat (2007:51) persepsi adalah pengalaman tentang objek, peristiwa atau hubungan-hubungan yang diperoleh dengan menyimpulkan informasi dan menafsirkan pesan.

Meskipun stimulus yang diterima sama, tetapi persepsi yang setiap orang berikan akan berbeda-beda. Hal ini dikarenakan adanya proses psikologis yang mengolah pengalaman, pengetahuan, dan perasaan. Begitu halnya persepsi mahasiswa terhadap profesi guru, mereka akan memberikan persepsi yang bebeda-beda berdasarkan apa yang mereka alami dan rasakan. Persepsi yang diberikan mahasiswa tentunya berbeda-beda, hal ini dikarenakan adanya beberapa faktor yang mempengaruhi.
Faktor yang mempengaruhi persepsi menurut Walgito (2004: 89-90) yaitu: (1) objek yang dipersepsi; (2) alat indera, syaraf, dan pusat susunan syaraf; dan (3) perhatian. Sedangkan menurut Shaleh (2010: 129) karena persepsi bersifat psikologis dibanding proses penginderaan saja maka ada beberapa faktor yang mempengaruhi, diataranya: (1) perhatian yang selektif; (2) ciri-ciri rangsangan; (3) nilai dan kebutuhan invidu; dan (4) pengalaman dahulu.

Persepsi mahasiswa terhadap profesi guru dapat diartikan sebagai suatu gagasan, pendapat, dan tanggapan mahasiswa terhadap pekerjaan yang mensyaratkan seseorang memiliki keahlian dalam dunia pendidikan sebagai pengajar dan ahli kependidikan lainnya. Di mana gagasan, pendapat dan tanggapan yang mahasiswa berikan diperoleh melalui proses penginderaan alat inderanya dan berdasarkan, kemampuan berpikir pengetahuan, pengalaman, perasaan, dan sudut pandangnya terhadap profesi guru.

Guru dapat dikatakan sebuah profesi karena menjadi guru dituntut suatu keahlian tertentu (Kusnandar, 2008: 45 dan Rahayu, 2007). Berdasarkan Undang-Undang Nomor 14 Tahun 2005, Guru adalah pendidik profesional dengan tugasnya mendidik, membimbing, melatih, menilai, dan mengevaluasi peserta didik pada pendidikan jalur pendidikan formal, pendidikan dasar, dan pendidikan menengah. Menurut Dewi (2015: 24); Leba dan Padmomartono (2014: 4); dan Noorjannah (2014: 98) guru sebagai tenaga profesional yang mempunyai wewenang, tanggung jawab, dan peran penting untuk mencapai visi dan peningkatan mutu pendidikan demi menciptakan insan Indonesia cerdas dan kompetitif.

Mendiknas RI, 2007 seorang guru harus memiliki kriteria minimal dan standar kompetensi guru. Tujuan dari standar kompetensi guru adalah untuk memperoleh acuan baku dalam pengukuran ki- 
nerja guru untuk mendapatkan jaminan kualitas guru dalam meningkatkan kualitas proses pembelajaran (Putro, 2012: 3). Standar kompetensi guru sebagai persyaratan minimal, maka seorang guru diharapkan mempunyai dan memenuhi standar tersebut sebagai persyaratan untuk menjalani profesi sebagai guru.

Terdapat empat standar kompetensi guru yang harus dikuasai yaitu kompetensi: pedagogik; kepribadian; sosial; dan profesional (Pemerintah RI, 2008, Musfah, 2011: 32; dan Mulyasa, 2013: 117). Selain menguasai empat kompetensi tersebut, seorang guru dituntut untuk memenuhi standar kualifikasi akademik. Kualifikasi akademik adalah ijazah jenjang pendidikan akademik yang harus dimiliki oleh guru atau dosen sesuai dengan jenis, jenjang, dan satuan pendidikan formal di tempat penugasan (UU No. 14 Tahun 2005).

Sebagai salah satu pekerjaan yang profesional, guru harus mempunyai sertifikat untuk menjalankan profesinya. Kusnandar (2008: 79) menyatakan sertifikat profesi guru diperoleh setelah mereka mengikuti sertifikasi dan dinyatakan memenuhi standar kualifikasi dan standar kompetensi guru. Penelitian yang telah dilakukan oleh Primadewi (2016) dan Suherdiyanto (2012) menyatakan bahwa persepsi mahasiswa terhadap profesi guru memiliki pengaruh dengan motivasi dan minat menjadi guru.

Berdasarkan penjabaran di atas, maka tujuan penelitian ini untuk: (1) mengungkap hubungan dan sumbangan adversity intelligence $\left(\mathrm{X}_{1}\right)$, persepsi mahasiswa terhadap profesi guru $\left(\mathrm{X}_{2}\right)$, dan kepercayaan diri untuk menjadi guru (Y) bagi mahasiswa Prodi S1 PTE Jurusan TE FT UM dan (2) mengungkap hubungan antara $\mathrm{X}_{1}$ dengan $\mathrm{Y}, \mathrm{X}_{2}$ dengan $\mathrm{Y}$, serta $\mathrm{X}_{1}$ dan $\mathrm{X}_{2}$ dengan $\mathrm{Y}$.

\section{METODE}

Berdasarkan permasalahan dan tujuan penelitian di atas, maka penelitian ini menggunakan metode penelitian expose facto dengan rancangan deskriptif korelasional. Penelitian deskriptif korelasional bertujuan untuk mengungkap apakah ada hubungan antara satu variabel dengan variabel lainya baik secara parsial maupun simultan yang hasil penelitiannya dipaparkan dalam bentuk laporan. Variabel penelitian ini yaitu: adversity intelligence $\left(\mathrm{X}_{1}\right)$ dan persepsi mahasiswa terhadap profesi guru $\left(\mathrm{X}_{2}\right)$ sebagai variabel bebas, serta kepercayaan diri menjadi guru $(\mathrm{Y})$ sebagai variabel terikat.

Populasi penelitian ini adalah mahasiswa Prodi S1 PTE Jurusan TE FT UM angkatan 2013 Universitas Negeri Malang sejumlah 109 mahasiswa, dengan teknik penentuan sampel yaitu purposive sampling. Purposive sampling merupakan teknik pengambilan sampel dengan kriteria tertentu (Sugiyono, 2013). Sampel penelitian ini sejumlah 106 responden dengan kriteria: mahasiswa Prodi S1 PTE Jurusan TE FT UM angkatan 2013; mahasiswa yang sudah menempuh matakuliah praktik pembelajaran mikro dan melaksanakan KPL; dan mahasiswa aktif semester genap.

Teknik pengumpulan data penelitian menggunakan instrumen penelitian berupa angket. Instrumen penelitian sebagai fasilitas peneliti dalam mengumpulkan data (Arikunto, 2010: 203). Pengumpulan data setiap variabel menggunakan angket penelitian yang diadaptasikan dengan skala likert. Di mana angket masing-masing variabel telah memenuhi syarat validitas dan realibilitas. Angket penelitian variabel Y diperoleh nilai alpha sebesar 0,93; dan angket variabel $\mathrm{X}_{1}$ diperoleh nilai alpha sebesar 0,90; sedangkan angket variabel $\mathrm{X}_{2}$ nilai alpha sebesar 0,95. 
Berdasarkan tujuan penelitian tersebut, maka analisis data yang digunakan yaitu analisa deskriptif dan untuk uji hipotesisnya menggunakan analisa korelasi parsial dan analisis regresi ganda. Sebelum uji hipotesis dilakukan, maka terlebih dahulu diuji prasyarat analisisnya. Di mana semua data penelitian telah memenuhi prasyarat analisis. Setelah data dinyatakan memenuhi prasyarat analisis, maka dapat dilakukan uji hipotesis yang disesuaikan dengan kebutuhan penelitian. pengambilan keputusannya berpedoman pada taraf signifikansi 0,05 .

\section{HASIL}

Hasil dari analisis statistik deskriptif untuk data variabel kepercayaan diri menjadi guru sebaran datanya seperti Tabel 1 .

Hasil dari analisis statistik deskriptif untuk data variabel adversity intelligence sebaran datanya seperti Tabel 2.

Hasil dari analisis statistik deskriptif untuk data variabel persepsi mahasiswa terhadap profesi guru dengan berbantuan SPSS sebaran datanya seperti Tabel 3. Hasil uji normalitas dengan KolmogorovSmirnov setiap variabel $\mathrm{X}_{1}, \mathrm{X}_{2}$, dan $\mathrm{Y}$ berturut-turut diperoleh nilai (p) yaitu 0,$067 ; 0,200 ; 0,200$. Di mana nilai tersebut di atas 0,05 yang artinya data terdistribusi normal. Hasil uji linearitas diperoleh bahwa $\mathrm{X}_{1}$ dengan $\mathrm{Y}$ terjadi hubungan linear dengan nilai $\mathrm{p}$ sebesar 0,000 . Sedangkan untuk $\mathrm{X}_{2}$ dengan $\mathrm{Y}$ juga terjadi hubungan yang linear dengan nilai $\mathrm{p}$ sebesar 0,000 .

Hasil uji multikolinearitas diperoleh nilai tolerance $\mathrm{X}_{1}$ dan $\mathrm{X}_{2}$ yaitu $0,614>$ 0,10 dan nilai VIF yaitu $1,628<10$. Dari angka-angka tersebut dapat diambil keputusan bahwa hubungan antara $\mathrm{X}_{1}$ dan $\mathrm{X}_{2}$ tidak terjadi multikolinearitas.

Hasil uji autokorelasi diperoleh nilai Durbin-Watson sebesar 2,035. Di mana
Tabel 1. Sebaran Data Kepercayaan Diri Menjadi Guru

\begin{tabular}{llll}
\hline Kriteria & Interval & $\mathbf{f}$ & \multicolumn{1}{c}{$(\boldsymbol{\%})$} \\
\hline Sangat Tinggi & $91-112$ & 27 & 25,47 \\
Tinggi & $70-90$ & 74 & 69,81 \\
Rendah & $49-69$ & 5 & 4,72 \\
Sangat Rendah & $28-48$ & 0 & 0 \\
\hline Total & & 106 & 100 \\
\hline
\end{tabular}

Tabel 2. Sebaran Data Adversity Intelligence

\begin{tabular}{llrl}
\hline Kriteria & Interval & f & \multicolumn{1}{c}{$(\boldsymbol{\% )}$} \\
\hline Sangat Tinggi & $94,8-120$ & 52 & 49,06 \\
Tinggi & $73,2-94,7$ & 50 & 47,17 \\
Rendah & $51,6-73,1$ & 4 & 3,77 \\
Sangat Rendah & $30-51,5$ & 0 & 0 \\
\hline Total & & 106 & 100 \\
\hline
\end{tabular}

Tabel 3. Sebaran Data Persepsi Mahasiswa terhadap Profesi Guru

\begin{tabular}{llll}
\hline Kriteria & Interval & f & \multicolumn{1}{c}{$(\mathbf{\%})$} \\
\hline Sangat Tinggi & $104-128$ & 74 & 69,81 \\
Tinggi & $79-103$ & 32 & 30,19 \\
Rendah & $56-79$ & 0 & 0 \\
Sangat Rendah & $32-55$ & 0 & 0 \\
\hline Total & & 106 & 100 \\
\hline
\end{tabular}

nilai ini di antara $\mathrm{dU} \leq \mathrm{DW} \leq(4-\mathrm{dU})$ yang artinya tidak terjadi autokorelasi.

Sedangkan untuk uji heteroskedastisita menggunakan diagram scatterplot. Di mana diagram tersebut menunjukkan pola yang tidak beraturan, titik-titiknya menyebar di bawah dan di atas titik nol sumbu Y. Dengan demikian dapat disimpulkan bahwa tidak terjadi heteroskedastisitas.

Uji hipotesis mengungkap hubungan parsial antara $\mathrm{X}_{1}$ dengan $\mathrm{Y}$ adalah positif dan signifikan dengan $r=0,636$ ( $\mathrm{sig}=$ $0,000<0,05)$. Hubungan parsial antara $\mathrm{X}_{2}$ dengan $\mathrm{Y}$ adalah positif dan tidak signifikan dengan $r=0,160(\operatorname{sig}=0,104$ $<0,05)$. Sedangkan untuk hubungan $\mathrm{X}_{1}$ dan $\mathrm{X}_{2}$ secara simultan dengan $\mathrm{Y}$ adalah positif dan signifikan diperoleh nilai $\mathrm{r}=$ 0,765 dan nilai $\mathrm{F}$ sebesar 72,873 (sig $=$ $0,000<0,05)$. Dari hasil penelitian 
didapat persamaan regresi $\mathrm{Y}=72,873+$ $0,577 X_{1}+0,117 X_{2}$.

Sumbangan relatif $\mathrm{X}_{1}$ dengan $\mathrm{Y}$ sebesar $87,50 \%$, sedangkan sumbangan relatif $\mathrm{X}_{2}$ dengan $\mathrm{Y}$ sebesar $12,5 \%$. Untuk sumbangan efektif $X_{1}$ sebesar $30,05 \%$ dan sumbangan efektif $X_{2}$ sebesar $4,30 \%$. Sedangkan sebesar $65,65 \%$ dipengaruhi oleh variabel dan faktor lain yang tidak diteliti dalam penelitian.

\section{PEMBAHASAN}

Dari hasil penelitian dapat dijelaskan bahwa sebagian besar mahasiswa Prodi S1 PTE Jurusan TE FT UM angkatan 2013 memiliki kepercayaan diri yang tinggi untuk menjadi guru. Berdasarkan beberapa indikator yang telah dijabarkan ke dalam instrumen kepercayaan diri menjadi guru diketahui bahwa ada indikator yang sangat berpengaruh, yaitu indikator pengendalian diri dalam kegiatan persekolahan. Menurut Fatimah (2006: 149) percaya diri adalah suatu sikap positif seseorang yang memampukan dirinya untuk mengendalikan diri baik terhadap diri sendiri, lingkungan, dan situasi yang sedang dihadapi.

Dalam hal ini dapat diartikan bahwa cerminan mahasiswa Prodi S1 PTE Jurusan TE FT UM yang memiliki kepercayaan diri yang tinggi untuk menjadi guru yaitu mempunyai sikap pengendalian diri yang baik dalam kegiatan persekolahan. Dengan kepercayaan diri yang mereka miliki mereka akan mampu mengendalikan berbagai macam kegiatan yang berkaitan dengan profesi guru.

Sedangkan indikator yakin terhadap kelebihan yang membuatnya mampu menjadi guru memperoleh nilai rerata yang rendah, dengan demikian indikator tersebut mempunyai pengaruh yang kecil terhadap variabel kepercayaan diri menjadi guru. Hal ini dapat diartikan bahwa keyakinan mahasiswa Prodi S1 PTE Jurusan TE FT UM terhadap ilmu yang te- lah mereka peroleh belum bisa meningkatkan kepercayaan diri mereka untuk menjadi guru, dengan kata lain mereka kurang yakin dengan pengetahuan dan pengalaman yang mereka miliki apakah dapat diterapkan langsung dalam kegiatan yang berkaitan dengan profesi guru.

Dari hasil penelitian dapat dijelaskan bahwa sebagian besar mahasiswa Prodi S1 PTE Jurusan TE FT UM angkatan 2013 memiliki tingkat adversity intelligence yang sangat tinggi untuk menjadi guru. Berdasarkan beberapa indikator yang telah dijabarkan ke dalam instrumen adversity intelligence diketahui bahwa indikator ketangguhan menghadapi kesulitan sebagai guru mempunyai pengaruh yang tinggi dalam variabel adversity intelligence. Tingkat adversity intelligence mahasiswa Prodi S1 PTE Jurusan TE FT UM dalam melaksanakan dan mempersiapkan segala sesuatu yang berkaitan dengan profesi guru tergantung dengan ketangguhan mereka dalam menghadapi setiap permasalahan yang ada di depannya.

Indikator bertahan dalam menghadapi tantangan sebagai guru memperoleh nilai rerata terendah, dengan demikian indikator tersebut mempunyai pengaruh yang kecil terhadap variabel adversity intelligence. Hal ini dapat diartikan bahwa mahasiswa Prodi S1 PTE Jurusan TE FT UM memiliki kemampuan bertahan yang rendah saat menghadapi tantangan sebagai guru.

Dari hasil penelitian dapat dijelaskan bahwa sebagian besar mahasiswa Prodi S1 PTE Jurusan TE FT UM angkatan 2013 memiliki persepsi yang sangat baik terhadap profesi guru. Persepsi mahasiswa terhadap profesi guru merupakan suatu proses psikologis mahasiswa yang menghasilkan gagasan, pendapat, dan tanggapan terkait pekerjaan atau jabatan yang mensyaratkan seseorang memiliki keahlian dalam dunia pendidikan sebagai pengajar dan ahli kependidikan lainnya. 
Berdasarkan beberapa indikator yang telah dijabarkan ke dalam instrumen persepsi mahasiswa terhadap profesi guru diketahui bahwa indikator aspek psikologis terhadap profesi guru mempunyai nilai rerata yang paling tinggi. Hal ini dapat diartikan bahwa indikator aspek psikologis terhadap profesi guru mempunyai pengaruh yang tinggi dalam variabel persepsi mahasiswa terhadap profesi guru. Persepsi didefinisikan sebagai proses yang menggabungkan dan mengorganisir data-data indera kita untuk dikembangkan dalam proses psikologis sehingga kita dapat menyadari di sekeliling kita (Shaleh, 2010: 110).

Indikator menafsirkan pesan terkait profesi guru memperoleh nilai rerata yang rendah, dapat diartikan bahwa indikator tersebut mempunyai pengaruh yang kecil terhadap variabel persepsi mahasiswa terhadap profesi guru. Indikator ini memiliki nilai terendah, karena sebagian mahasiswa menganggap bahwa profesi guru harus memiliki kepribadian dan jiwa sosial yang tinggi. Hal inilah yang menyebabkan mahasiswa enggan memberi persepsi yang baik, karena mereka merasa kepribadian dan jiwa sosial yang mereka miliki belum sesuai dengan kriteria menjadi guru.

Diketahui bahwa $\mathrm{X}_{1}$ dengan $\mathrm{Y}$ memiliki hubungan positif dan signifikan. Mahasiswa yang mempunyai adversity intelligence yang tinggi cenderung mempunyai keyakinan kuat terhadap kemampuan yang dimiliki, diharapkan mahasiswa mampu mengendalikan dan mengatasi berbagai tantangan dan rintangan untuk menjadi guru, hal ini dapat meningkatkan kepercayaan diri mahasiswa menjadi guru. Dengan demikian dapat dikatakan bahwa peningkatan kepercayaan diri menjadi guru serasi dengan peningkatan tingkat adversity intelligence.

Diketahui bahwa $\mathrm{X}_{2}$ dengan $\mathrm{Y}$ memiliki hubungan positif dan tidak signifikan. Dari hasil penelitian tersebut dike- tahui bahwa persepsi mahasiswa terhadap profesi guru tidak dapat berdiri sendiri untuk mempengaruhi kepercayaan diri menjadi guru mahasiswa, perlu faktor lain yang dapat mendukung persepsi mahasiswa diantaranya motivasi dan minat.

Diketahui bahwa $\mathrm{X}_{1}$ dan $\mathrm{X}_{2}$ dengan $Y$ memiliki hubungan positif dan signifikan. Hal tersebut dapat dijelaskan bahwa peningkatan kepercayaan diri menjadi guru mahasiswa Prodi S1 PTE Jurusan TE FT UM selaras dengan peningkatan adversity intelligence dan persepsi mahasiswa terhadap profesi guru. Peningkatan kepercayaan diri mahasiswa menjadi guru perlu diberikan pengetahuan dan pengalaman yang dapat melatih adversity intelligence dan memberikan persepsi yang positif, diberikan motivasi, arahan, dan dorongan yang nantinya dapat menumbuhkan kepercayaan diri mahasiswa Prodi S1 PTE Jurusan TE FT UM untuk berprofesi menjadi guru sekaligus terjun langsung dalam dunia pendidikan.

\section{SIMPULAN DAN SARAN}

Berdasarkan hasil analisis data dan pembahasan yang telah dipaparkan, maka dapat diperoleh kesimpulan yaitu: mahasiswa Prodi S1 PTE Jurusan TE FT UM memiliki kepercayaan diri menjadi guru yang tinggi, memiliki tingat adversity intelligence dalam kategori yang sangat tinggi, dan memiliki persepsi yang sangat baik terhadap profesi guru. Penelitian ini mengungkap adanya hubungan positif dan signifikan antara adversity intelligence dan persepsi mahasiswa terhadap profesi guru dengan kepercayaan diri menjadi guru bagi mahasiswa Prodi S1 PTE Jurusan TE FT UM. Hal ini dapat diartikan bahwa adversity intelligence dan persepsi mahasiswa terhadap profesi guru dapat mempengaruhi kepercayaan diri menjadi guru bagi mahasiswa Prodi S1 PTE Jurusan TE FT UM. 
Berdasarkan kesimpulan di atas, dapat diajukan saran sebagai berikut. (1) Kepercayaan diri mahasiswa Prodi S1 PTE Jurusan TE FT UM dalam kategori tinggi, hal ini perlu dipertahankan sekaligus ditingkatkan untuk kedepannya. Kepercayaan diri tersebut merupakan langkah awal mahasiswa untuk menjalankan praktik micro teaching, KPL dan mempersiapkan diri untuk berprofesi menjadi guru. (2) Tingkat adversity intelligence mahasiswa S1 Prodi S1 PTE Jurusan TE FT UM cenderung dalam kategori sangat tinggi, dengan demikian dapat dikatakan bahwa proses perkuliahan yang dilaksanakan Prodi S1 PTE Jurusan TE FT UM telah mampu memberikan pengalaman yang sangat berpengaruh dalam membentuk adversity intelligence mahasiswa. Proses perkuliahan yang bersifat teori maupun praktik, telah mampu melatih mahasiswa dalam menghadapi dan mengendalikan kesulitan yang sedang dihadapi. Proses perkuliahan seperti inilah yang seharusnya selalu didukung sekaligus dipertahankan, demi mencetak lulusan yang dapat diandalkan dan mempunyai daya juang yang tinggi dalam memasuki dunia kerja khususnya profesi sebagai guru.

Sebagai mahasiswa yang dididik untuk menjadi calon guru sudah selayaknya memiliki persepsi yang baik tentang profesi guru. Persepsi inilah yang nantinya dapat membentuk kepercayaan diri mahasiswa untuk menjadi guru. Namun persepsi mahasiswa terhadap profesi guru tidak dapat berdiri sendiri dalam mempengaruhi kepercayaan diri menjadi guru, persepsi perlu didukung dengan motivasi dan minat menjadi guru seorang mahasiswa.

Bagi seluruh dosen dan pihak yang terlibat dalam proses perkuliahan, sudah seharusnya bekerjasama dalam tercapainya visi misi Prodi S1 PTE Jurusan TE FT UM. Selain itu diharapkan bagi seluruh dosen dan pihak yang terlibat mem- berikan motivasi sekaligus arahan untuk berprofesi menjadi guru, sehingga mahasiswa Prodi S1 PTE Jurusan TE FT UM memiliki antusias dan animo yang tinggi untuk menjadi guru.

\section{DAFTAR RUJUKAN}

Anomsari, D.R. 2011. Hubungan Kemampuan Adversity dan Intensi Berwirausaha pada Siswa SMK Yayasan Pendidikan Ma'arif 1 Taman Sidoarjo. Skripsi tidak diterbitkan. Malang: FIP UM.

Arikunto, S. 2010. Prosedur Penelitian suatu Pendekatan Praktik. Jakarta: Rineka Cipta.

Asfarina, L.M. 2016. Keefektifan Psikoedukasi Menggunakan Teknik Lead dan Lead Plus Impact untuk Meningkatkan Adversity Intelligence Siswa SMK. Tesis tidak diterbitkan. Malang: Pascasarjana UM.

Azhar, M. 2015. Hubungan antara Kepercayaan Diri dengan Minat Berorganisasi pada Anggota Koperasi Mahasiswa di Yogyakarta. Skripsi tidak diterbitkan. Yogyakarta: FISHUM UIN Sunan Kalijaga.

Dewi, T.A. 2015. Pengaruh Profesionalisme Guru dan Motivasi Kerja terhadap Kinerja Guru Ekonomi SMA se-Kota Malang. Jurnal Pendidikan Ekonomi UM Metro, (Online), 3(1): 24-35, (http://download.Portalgaruda.org/article, diakses 3 November 2016.)

Fatimah, E. 2006. Psikologi Perkembangan: Perkembangan Peserta Didik. Bandung: Pustaka Setia.

Fitriawati, L.R. 2013. Hubungan Tingkat Keterlaksanaan Praktik Pengalaman Lapangan (PPL) dengan Ketertarikan menjadi Guru bagi Mahasiswa Calon Guru Jurusan Teknik Elektro Universitas Negeri Malang Semester Gasal 2012/2013. Malang: FT UM. 
Hakim, T. 2005. Mengatasi Rasa Tidak Percaya Diri. Jakarta: Puspa Swara.

Kusnandar. 2008. Guru Profesional: Implementasi Kurikulum Tingkat Satuan Pendidikan (KTSP) dan Sukses dalam Sertifikasi Guru. Jakarta: Raja Grafindo Persada.

Leba, U.T.I. \& Padmomartono, S. 2014. Profesi Kependidikan. Yogyakarta: Ombak (Anggota IKAPI).

Mendiknas RI.2007. Peraturan Menteri Pendidikan Nasional Nomor 16 Tahun 2007 tentang Standar Kualifikasi Akademik dan Kompetensi Guru Jakarta: Mendiknas.

Mulyasa, E. 2013. Standar Kompetensi dan Sertifikasi Guru (Mukhlis, Ed.). Bandung: Remaja Rosdakarya.

Musfah, J. 2011. Peningkatan Profesi Guru: melalui Pelatihan dan Sumber Belajar Teori dan Praktik. Jakarta: Kencana.

Noorjannah, L. 2014. Pengembangan Profesionalisme Guru melalui Penulisan Karya Tulis Ilmiah bagi Guru Profesional di SMA Negeri 1 Kauman Kabupaten Tulungagung. Jurnal Humanity, (Online), 10(1): 97--114, (http://ejournal.umm.ac.id/ index.php/humanity/article/viewFile/ 2459/2667, diakses 3 November 2016).

Pemerintah RI . 2008. Peraturan Pemerintah RI No. 74 Tahun 2008 tentang Guru. (Online), (http://disdik.katimprov.go.id, diakses 6 November 2016).

Primadewi, A.H. 2016. Hubungan Keteladanan Dosen dan Persepsi Mahasiswa terhadap Karir Kegururan dengan Minat Mnenjadi Guru pada Mahasiswa Program Studi S1 Pendidikan Teknik Elektro Fakultas Teknik Universitas Negeri Malang. Skripsi tidak diterbitkan. Malang: FT UM.

Putro, S.C. 2012. Perencanaan Pembelajaran: Bahan Ajar. Malang.
Rahayu, N. 2007. Pengaruh Minat pada Profesi Guru terhadap Motivasi dan Prestasi Belajar Mahasiswa Program Studi Pendidikan Akutansi Fakultas Ekonomi Universitas Negeri Malang. Skripsi tidak diterbitkan. Malang: FE UM.

Rakhmat, J. 2007. Psikologi Komunikasi. Bandung: Remaja Rosdakarya.

Setyawan, I. 2011. Peran Keterampilan Belajar Konstektual dan Kemampuan Empati terhadap Adversity Intelligence pada Mahasiswa. Jurnal Psikologi Undip, (Online), 9(1): 4049 (http://ejournal.undip.ac.id, diakses 25 Oktober 2016).

Shaleh, A.R. 2010. Psikologi: Suatu Pengantar dalam Perspektif Islam. Jakarta: Kencana.

Sugiyono, 2013. Metode Penelitian Pendidikan (Pendekatan Kuantitatif, Kualitatif, dan $R \& D)$. Bandung: Alfabeta.

Suherdiyanto, T. 2012. Pengaruh Persepsi Mahasiswa Program Studi Teknik Bangunan (PTB) tentang Profesi Guru terhadap Motivasi untuk Menjadi Guru (Studi pada Mahasiswa Angkatan UM 2007-2009). Skripsi tidak diterbitkan. Malang: FT UM.

Thoha, M. 2004. Perilaku Organisasi: Konsep Dasar dan Aplikasinya. Jakarta: Raja Grafindo Persada.

Undang-undang RI No. 14 Tahun 2005 tentang Guru dan Dosen. (Online), (https://kelembagaan.ristek.go.id, diakses 6 November 2016).

Universitas Negeri Malang, 2014. Katalog Universitas Negeri Malang Edisi 2014. Malang: UM Press.

Walgito, B. 2004. Pengantar Psikologi Umum. Yogyakarta: Andi.

Wijaya, T. 2007. Hubungan Adversity Intelligence dengan Intensi Berwirausaha. Jurnal Manajemen dan Kewirausahaan, (Online), 9(2): 117-127, (https://jurnalmanajemen.petra.ac.id, diakses 25 Oktober 2016). 